Canadian

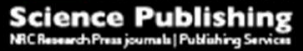

Botany

Botanique

\title{
Interactions of arbuscular mycorrhizal fungi, critical loads of nitrogen deposition, and shifts from native to invasive species in a southern California shrubland
}

\begin{tabular}{|r|l|}
\hline Journal: & Botany \\
\hline Manuscript ID & cjb-2015-0266.R1 \\
\hline Danuscript Type: & Review \\
\hline Complete List of Authors: & $\begin{array}{l}\text { Allen, Edith; University of California, Botany and Plant Sciences } \\
\text { Egerton-Warburton, Louise; Chicago Botanic Garden, Plant Science Center } \\
\text { Hilbig, Bridget; University of California Riverside, Botany and Plant } \\
\text { Sciences } \\
\text { Valliere, Justin; University of California, Botany and Plant Sciences }\end{array}$ \\
\hline Keyword: & $\begin{array}{l}\text { fine endophyte, Glomus tenue, nitrogen critical load, vegetation-type } \\
\text { conversion }\end{array}$ \\
\hline & \\
\hline \multicolumn{2}{|c}{} \\
\hline
\end{tabular}

SCHOLARONE ${ }^{\text {M }}$

Manuscripts 


\section{Interactions of arbuscular mycorrhizal fungi, critical loads of}

2 nitrogen deposition, and shifts from native to invasive species in a

\section{3 southern California shrubland}

4

5 Edith B. Allen, Louise M. Egerton-Warburton, Bridget E. Hilbig, and Justin M. Valliere 6

7 E.B. Allen, Department of Botany and Plant Sciences, University of California,

8 Riverside, Riverside, California 92521 U.S.A. email: edith.allen@ucr.edu

9 L. M. Egerton-Warburton, Chicago Botanic Garden, Plant Science Center, 1000 Lake

10 Cook Rd, Glencoe IL 60022 email: lwarburton@chicagobotanic.org

11 B.E Hilbig, Department of Botany and Plant Sciences, University of California,

12 Riverside, Riverside, California 92521 U.S.A. email: bridget.hilbig@ucr.edu

13 J.M. Valliere, Department of Botany and Plant Sciences, University of California,

14 Riverside, Riverside, California 92521 U.S.A. email: jvall007@ucr.edu

15 Corresponding author: Edith B. Allen (email: edith.allen@ucr.edu, tel. 951-827-2123,

16 fax 951-827-4437)

17

18 
19 Abstract: Anthropogenic nitrogen (N) deposition and invasive species are causing

20 declines in global biodiversity, and both factors impact the diversity and functioning

21 of arbuscular mycorrhizal fungi (AMF). Shifts in AMF communities also have

22 feedbacks on native plant success, as was observed in California coastal sage scrub,

23 a Mediterranean-type shrubland threatened by invasive grasses. As vegetation-type

24 conversion from native shrubland to exotic annual grassland increased along a

25 gradient of increasing $\mathrm{N}$ deposition, the richness of native plant species and of AMF

26 spore morphotypes decreased. Rapid declines in all plant and fungal values

27 occurred at a critical load (CL) of 10-11 $\mathrm{kg} \mathrm{N} \mathrm{ha}^{-1} \mathrm{yr}^{-1}$, indicating that AMF respond to

28 the same environmental signals as the plants and can be used to assess CL. Shrub

29 root colonization also decreased along the $\mathrm{N}$ gradient, but colonization of the

30 invasive grass was dominated by a fine AMF endophyte that was unresponsive to

31 elevated N. A greenhouse experiment to assess AMF functioning showed that the

32 native shrub Artemisia californica had a negative growth response to inoculum from

33 high-N but not low-N soils, while the invasive grass Bromus rubens had a positive

34 response to both inocula. Differential functioning of AMF under $\mathrm{N}$ deposition may in

35 part explain vegetation-type conversion and the decline of this native shrubland.

37 Keywords: fine endophyte, Glomus tenue, nitrogen critical load, vegetation-type

38 conversion

39

40

41 


\section{Introduction}

43 Anthropogenic nitrogen $(\mathrm{N})$ deposition has recently been documented as a

44 cause of decline of shrub- and grassland ecosystems (Fenn et al. 2010; Bobbink

45 2010; Rao et al. 2010; Cox et al. 2014). These ecosystems are subject to loss of

46 native plant diversity (Stephens et al. 2010) and vegetation-type conversion to

47 exotic annual grasslands (Fenn et al. 2010; Rao et al. 2010; Cox et al. 2014). Such

48 conversions may be mediated by the direct effects of $\mathrm{N}$ fertilization on plants with

49 traits that make some species more productive or competitive than others (Suding

50 et al. 2005; Dimbock et al. 2014), or indirectly through the effects of $\mathrm{N}$ on

51 mycorrhizal fungi. Elevated $\mathrm{N}$ causes decreases in arbuscular mycorrhizal fungal

52 (AMF) root colonization and spore production (Egerton-Warburton and Allen 2000;

53 Johnson et al. 2003; Egerton-Warburton et al. 2007; van Diepen et al. 2011), and a

54 predominance of poor AMF mutualists that promote reduced growth of host plants

55 (Johnson 1993).

56 Invasive species increase under $\mathrm{N}$ deposition when they are more responsive

57 to $\mathrm{N}$ than native species (Rao and Allen 2010). These invasive species have direct

58 impacts on native species composition (Cox et al. 2008, Steers et al. 2011), which

59 may also be mediated by mycorrhizal fungi (Marler et al. 1999; Pringle et al. 2009).

60 Furthermore, invasive species cause feedbacks on soil microbial composition,

61 including shifts in AMF species composition and diversity reductions (Sigüenza and

62 Allen 2006a; Mummey and Rillig 2008; Barto et al. 2011; Busby et al. 2012; Hilbig

63 and Allen 2015). Shifts in AMF species composition have important feedbacks to

64 their hosts by changing the physiological response of their host plants, and plant 
65 species responses to AMF infection vary within a plant community by AMF species

66 identity and plant species dependence on AMF (Allen et al. 2003; Klironomos 2003).

67 In southern California, which receives high levels of $\mathrm{N}$ deposition due to air

68 pollution (Fenn et al. 2010), N deposition has been implicated in the widespread

69 conversion of coastal sage scrub (CSS) to exotic annual grasslands (Allen et al. 1998;

70 Fenn et al. 2010; Cox et al. 2014). Coastal sage scrub is a drought-deciduous

71 Mediterranean-type shrubland with high species richness and endemism that has

72 been reduced to a small fraction of its historic range as a result of land-use change,

73 invasion and increased fire frequency. It is one of the most endangered ecosystems

74 globally with losses in plant species richness across much of its range (Cleland et al.

75 2016). The role of mycorrhizae in the interactions between exotic annual grasses

76 and native shrubs has been tested (Yoshida and Allen 2004; Sigüenza and Allen

77 2006b), but the role of AMF in the shift to exotic annual grasslands has not been

78 considered on the landscape scale, and will be considered here.

79 Furthermore, the decline in AMF, similar to the decline in native plant

80 species richness, may be used as an indicator of critical load (CL) for N deposition. A

81 CL for $\mathrm{N}$ deposition is that amount of $\mathrm{N}$ below which there are no negative impacts

82 on an ecosystem (Pardo et al. 2011). These can be measured as changes in structure

83 (e.g., species richness, vegetation-type conversion) or function (e.g., mycorrhizal

84 functioning, increased fire due to invasion). Cox et al. (2014) calculated a CL of $11 \mathrm{~kg}$

$85 \mathrm{~N} \mathrm{ha}^{-1} \mathrm{yr}^{-1}$ for the shift from native CSS to exotic annual grassland dominated by

86 Mediterranean invasive grasses, but this study was focussed on vegetation rather

87 than AMF. 
88 During the last 20+ years, we have undertaken a series of studies to

89 understand how anthropogenic $\mathrm{N}$ deposition affects plants and AMF of CSS. The

90 objectives of this review are to synthesize previous studies on the relationships

91 between $\mathrm{N}$ deposition, native and invasive species, and AMF activity, especially

92 pertaining to CSS, and to compare this information with a more recent analysis of CL

93 for $\mathrm{N}$ deposition in CSS (Cox et al. 2014). The specific objectives are to review (1)

94 impacts of $\mathrm{N}$ deposition on abundance of native and invasive species of CSS in

95 California; (2) impacts of N deposition on arbuscular mycorrhizal diversity and

96 activity; (3) critical loads for $\mathrm{N}$ deposition impacts on AMF and relate these to CL for

97 vegetation-type conversion; and (4) functional responses of native and invasive

98 species to shifts in AMF diversity and to elevated N.

\section{Nitrogen deposition gradient in coastal sage scrub}

101 Before proceeding with $\mathrm{N}$ deposition impacts on AMF and associated CSS

102 vegetation, we review the $\mathrm{N}$ deposition values that occur in this vegetation type.

103 After the EPA Community Multiscale Air Quality (CMAQ) model of N deposition for

104 California became available (Fenn et al. 2010), we were able to calculate critical

105 loads of $\mathrm{N}$ deposition for impacts on plants and AMF. The California version of

106 CMAQ was generated at a $4 \times 4 \mathrm{~km}$ scale for 2002, which provides finer resolution

107 than the $12 \times 12 \mathrm{~km}$ national CMAQ model. The $\mathrm{N}$ deposition values in southern

108 California CSS range from 2 to $20 \mathrm{~kg} \mathrm{~N} \mathrm{ha}^{-1} \mathrm{yr}^{-1}$ (Allen et al. 2014), with 2 being the

109 background level in unpolluted areas and 20 the highest value in wildland areas

110 downwind of urban Los Angeles. The range of high values across the U.S. is also >20 
$111 \mathrm{~kg} \mathrm{~N} \mathrm{ha}^{-1} \mathrm{yr}^{-1}$ (NADP 2013) so values for $\mathrm{N}$ deposition in CSS are as high as any found

112 in the U.S. By contrast, the highest values in a European grassland N deposition

113 gradient were near $40 \mathrm{~kg} \mathrm{~N} \mathrm{ha}^{-1} \mathrm{yr}^{-1}$ (Stephens et al. 2010), i.e. higher than recorded

114 U.S. values. Both oxidized and reduced forms of $\mathrm{N}$ are deposited, as nitrate/nitric

115 acid from internal combustion, and ammonia/ammonium from agriculture and

116 catalytic converters (Fenn et al. 2010). About $90 \%$ is deposited in the dry form

117 during the long summer dry season in this Mediterranean-type climate and

118 accumulates on soil surfaces (Padgett et al. 1999, Bytnerowicz et al. 2016). The N

119 deposition gradient we studied was in CSS in western Riverside County, and ranged

120 from 8.7 to $19.6 \mathrm{~kg} \mathrm{~N} \mathrm{ha}^{-1} \mathrm{yr}^{-1}$ (Fig. 1).

121

122 Growth of individual CSS plants under elevated N

123 Elevated $\mathrm{N}$ preferentially increases the growth and rate of $\mathrm{N}$ uptake of the

124 dominant invasive grass Bromus rubens (= B. madritensis subsp. rubens) over the

125 dominant native shrub it is displacing Artemisia californica (Yoshida and Allen 2001;

126 2004). When individuals of B. rubens and A. californica were grown individually in

127 pots in sterile soil, growth rates of both species were similar, although mortality of $A$.

128 californica was high at the highest level of $\mathrm{N}$ fertilization (Padgett and Allen 1999).

129 However, when individuals were grown in non-sterile soil, AMF-colonized roots of $B$.

130 rubens acquired labeled ${ }^{15} \mathrm{NH}_{4}^{+}$(but not ${ }^{15} \mathrm{NO}_{3}^{-}$) at a higher rate than $A$. californica

131 (Yoshida and Allen 2004). This suggests that B. rubens can take up $\mathrm{N}$ from $\mathrm{NH}_{4}^{+}-$

132 dominated field soils (most of the soils in the region are slightly acidic in $\mathrm{pH}$ and

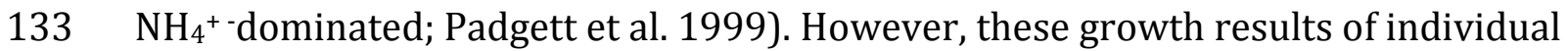


134 plants in pots are insufficient to explain the role of $\mathrm{N}$ deposition and AMF in the shift

135 from shrubland to grassland, and further studies in the field plus greenhouse are

136 presented that are more revealing.

138 Plant community shifts in response to $\mathbf{N}$ fertilization and AMF implications

139 Studies in California grasslands have shown that $\mathrm{N}$ fertilization or $\mathrm{N}$

140 deposition increases exotic annual grasses preferentially over native grasses and

141 forbs (Huenneke et al. 1990, Weiss 1999). Similarly, invasive grasses increased in

142 abundance in southern California CSS with increased N availability (Fig. 2a, b). CSS

143 vegetation was fertilized beginning 1994 with $60 \mathrm{~kg} \mathrm{~N} \mathrm{ha}^{-1} \mathrm{yr}^{-1}$ as $\mathrm{NH}_{4} \mathrm{NO}_{3}$ following

144 a 1993 wildfire in an area of relatively low $\mathrm{N}$ deposition (Fig. 2a, b). The biomass of

145 exotic annual grasses (predominantly B. rubens) increased in N-fertilized plots,

146 while the cover of native shrubs, dominated by A. californica, decreased. As this

147 community reassembled from bare ground following the fire, competition from

148 productive, $\mathrm{N}$-fertilized $B$. rubens likely reduced shrub seedling establishment, as

149 was previously demonstrated in a grass removal experiment (Eliason and Allen

150 1997). However, AMF may also be implicated, as AMF colonization of native shrub

151 roots was lower in plots with elevated N (Egerton-Warburton and Allen 2000;

152 Sigüenza et al. 2006b), but there was no significant difference in AMF colonization

153 between N-fertilized and unfertilized B. rubens roots in these plots (Sigüenza et al.

154 2006b). Loss of AMF may negatively impact the hyphal network that promotes

155 water transport to shrubs during the summer dry season (Allen et al. 2010,

156 Querejeta et al. 2012), further reducing their growth. 


\section{Critical load for loss of plant richness on a $\mathbf{N}$ deposition gradient}

159 The $\mathrm{N}$ fertilization experiments reported above confirmed the patterns in

160 native and invasive species shifts on the $\mathrm{N}$ deposition gradient, where native species

161 richness declined from 67 to 15 species between 8.7 to $19.6 \mathrm{~kg} \mathrm{~N} \mathrm{ha}^{-1} \mathrm{yr}^{-1}$ (Allen et al.

162 2014; Table 1). Based on the steep drop in species richness between 9.6 and $11 \mathrm{~kg} \mathrm{~N}$

$163 \mathrm{ha}^{-1} \mathrm{yr}^{-1}$, we estimated that the CL for species richness loss is $\sim 10 \mathrm{~kg} \mathrm{~N} \mathrm{ha}^{-1} \mathrm{yr}^{-1}$.

164 Percent cover of native forbs and shrubs also declined steeply along this gradient,

165 while cover of invasive annual grasses increased (Table 1). The low level of $\mathrm{N}$

166 deposition we observed in this CSS gradient is not the lowest level of $\mathrm{N}$ found in

167 southern California, and precludes testing the response at lower levels at this site.

168 For instance, impacts of $\mathrm{N}$ deposition on plant species richness in European

169 grasslands were reported by Stephens et al. (2010), who observed species losses

170 over an $\mathrm{N}$ deposition range of 2 to $40 \mathrm{~kg} \mathrm{~N}^{-1} \mathrm{yr}^{-1}$. However, lower levels of $\mathrm{N}$

171 deposition occur in the Venturan (coastal) association of CSS, and this $\mathrm{N}$ gradient is

172 the topic of current research in the Santa Monica Mountains. Studying a gradient

173 with lower $\mathrm{N}$ deposition may result in a lower CL for loss of species richness.

174 This observation of CL for loss of plant species richness is based on relatively

175 few sites in which a steep drop in richness occurs above $9.6 \mathrm{~kg} \mathrm{~N} \mathrm{ha}^{-1} \mathrm{yr}^{-1}$. To

176 confirm this value, a more rigorous approach to estimate CL was taken by

177 quantifying vegetation-type conversion from native shrubland to exotic annual

178 grassland (Cox et al. 2014). A vegetation survey from 1930 was compared with a

179 modern resurvey from 2002 . The analysis of 150 sites showed that $35 \%$ of CSS 
180 converted to exotic grassland within 72 years, and mostly in areas with high $\mathrm{N}$

181 deposition. The probability of type-conversion to exotic grassland increased steeply

182 at $11 \mathrm{~kg} \mathrm{~N} \mathrm{ha}^{-1} \mathrm{yr}^{-1}$ (Cox et al. 2014). We took this to be the CL for vegetation-type

183 conversion, similar to the CL for richness loss (Table 1).

184

185 AMF activity across $\mathbf{N}$ gradients as indicators of critical load

186 A similar loss of AMF spore morphospecies, reduced percent root

187 colonization and spore density in rhizospheres of native CSS shrubs (A. californica,

188 Encelia farinosa, Eriogonum fasciculatum) occurred on this N gradient (Egerton-

189 Warburton and Allen 2000; Table 2, Table 3). Root colonization declined from 45 to

$19019 \%$ and spore density declined from 105 to 23 spores/g soil with elevated N (Table

191 2). A total of 24 species of AMF were observed, with 19 being the highest number at

192 any site (Table 3; Egerton-Warburton and Allen 2000). Spore species richness

193 declined from 19 to 11 per site across the $\mathrm{N}$ gradient. The greatest decline was in

194 the 8 species of large-spored genera (Scutellospora [3 species], Acaulospora [2

195 species], Gigaspora, Entrophospora, and Sclerocystis [1 species each]), which

196 declined from a total of $37 \%$ to $7 \%$ of the total species richness with elevated $\mathrm{N}$

197 (Table 3). The remaining 16 species were all Glomus spp. Glomus aggregatum was

198 the most abundant species in density at all sites, and increased further with elevated

199 N. Other Glomus species either declined in density with elevated N or showed no

200 discernible pattern in response to N (Egerton-Warburton and Allen 2000).

201 The declines in AMF richness and percent colonization were primarily a

202 function of elevated $\mathrm{N}$ rather than host species (shrub vs. grass). We believe this to 
203 be the case because soil and root samples were collected under shrubs that

204 occurred in remnant patches even in regions with high $\mathrm{N}$ deposition. Rhizosphere

205 soils of grasses were not collected for this study (Egerton-Warburton and Allen

206 2000). Furthermore, exotic grasses occur throughout the gradient, although more

207 extensively across the landscape under elevated $\mathrm{N}$ deposition. A reduction in shrub

208 root colonization with elevated $\mathrm{N}$ may be triggered by molecular signaling and

209 reduced provisioning of photosynthate to AMF (reviewed in Egerton-Warburton et

210 al. 2000; Johnson et al. 2003). Soils of this region are relatively high in phosphorus

211 with $30 \mu \mathrm{g} / \mathrm{g}$ P (Padgett et al. 1999). Reduced mycorrhizal activity following N

212 eutrophication is especially pronounced in soils with initially low N:P ratios, such

213 that elevated $\mathrm{N}$ causes both $\mathrm{N}$ and $\mathrm{P}$ to be in high supply (Johnson et al. 2003).

214 Preferential loss of large-spored species with elevated N may be related to their

215 greater carbohydrate demand for reproduction (reviewed in Egerton-Warburton

216 and Allen 2000, Egerton-Warburton et al. 2007).

217 The patterns in reduction of AMF activity are largely similar to loss of plant

218 species richness under N deposition. The CL for decline of AMF activity is above 9.6

$219 \mathrm{~kg} \mathrm{~N} \mathrm{ha}^{-1} \mathrm{yr}^{-1}$ (Tables 2, 3). This corresponds to plant species richness decline above

$2209.6 \mathrm{~kg} \mathrm{~N} \mathrm{ha}^{-1} \mathrm{yr}^{-1}$ (Table 1) and vegetation type conversion at $\sim 11 \mathrm{~kg} \mathrm{~N} \mathrm{ha}^{-1} \mathrm{yr}^{-1} \mathrm{from}$

221 native shrubland to exotic annual grassland (Cox et al. 2014). Both decreased shrub

222 AMF activity and loss of plant species richness are related to increased soil N, but

223 native plant richness decline is also related to increased invasive grass productivity.

224 This suggests AMF spore richness and percent infection of shrub roots can be used

225 as indicators of elevated $\mathrm{N}$, as they declined under sparse, remaining shrubs 
226 sampled in the high deposition sites (Egerton-Warburton and Allen 2000).

227 Alternatively, the grasses tend to form associations with fine AMF (Siguenza et al.

228 2006a; 2006b; Hilbig and Allen 2015), which might cause a decline in spore richness

229 even in the absence of $\mathrm{N}$ deposition. However, spore richness was not quantified for

230 grass rhizospheres. In support of our shrub rhizosphere analysis, a retrospective

231 study using archived soil samples from a higher elevation chaparral site in the Los

232 Angeles air basin showed a decline in density of all spore species and a loss of large

233 spored genera between 1937 and 1961, with further declines through 1999

234 (Egerton-Warburton et al. 2001). In this site, soil $\delta^{15} \mathrm{~N}$ values (an indicator of $\mathrm{N}$

235 emissions from internal combustion) were elevated since at least 1958. As a result,

$236 \mathrm{~N}$ deposition has affected AMF activity for a sufficient time to cause feedbacks to the

237 plant community.

238

239 Feedbacks of N-fertilized AMF inoculum on invasive and native plant species

240 Another analysis of AMF activity was done along the same $\mathrm{N}$ deposition

241 gradient (Egerton-Warburton and Allen 2000), that included the invasive grass $B$.

242 rubens as well as the native shrub A. californica (Sigüenza et al. 2006b). Spore

243 counts (richness was not assessed) in the rhizosphere of the invasive grass did not

244 decline significantly with elevated soil N, while spore counts of the native shrub

245 decreased, the latter also observed by Egerton-Warburton and Allen (2000).

246 Furthermore, approximately one-half of $B$. rubens root colonization was by a fine

247 AMF endophyte, Glomus tenue (with up to $80 \%$ total root infection, sum of coarse

248 plus fine endophyte). In contrast, A. californica roots showed only traces of fine 
249 AMF colonization (Sigüenza et al. 2006b), while G. tenue spores and root infection

250 were not observed in shrub rhizospheres by Egerton-Warburton and Allen (2000).

251 The next step was to determine whether there is a functional response of

252 mycorrhizal fungi in the success of B. rubens and the poor performance of $A$.

253 californica under $\mathrm{N}$ deposition.

254 We report on a greenhouse study to demonstrate feedbacks of N-deposition

255 altered AMF communities on growth of B. rubens and A. californica (Sigüenza et al.

256 2006a). Three inoculum treatments from this study were: A) soil inoculum from

257 low $\mathrm{N}$ deposition site (8 $\mathrm{kg} \mathrm{N} \mathrm{ha}^{-1} \mathrm{yr}^{-1}$ ); B) soil inoculum from high $\mathrm{N}$ deposition site

258 (20 kg N ha-1 $\mathrm{yr}^{-1}$ ); and C) sterile soil (sterilized inoculum from high deposition and

259 low deposition sites to balance the nutrients). Each of the inoculum treatments was

260 given a high or low $\mathrm{N}$ fertilizer treatment. The potting mix was soil from the low $\mathrm{N}$

261 deposition site, and the $\mathrm{N}$ fertilization treatment had added $\mathrm{NH}_{4} \mathrm{NO}_{3}$ to increase $\mathrm{N}$ to

262 levels found in soils of the high $\mathrm{N}$ deposition site.

263 Bromus rubens responded positively to both inoculum sources in comparison

264 to sterile controls in low N soil, but there were no significant effects of inoculum in

265 high N soil (Fig. 3a). Conversely, A. californica seedlings had a negative response to

266 inoculum in high and low $\mathrm{N}$ soils, and inoculum from high $\mathrm{N}$ deposition soil was

267 especially detrimental to its growth. The greenhouse study of Sigüenza et al.

268 (2006a) was done under a moderate water regime, i.e., pots were watered to field

269 capacity and surface soils allowed to dry without wilting seedlings. Recently, we

270 performed a variation on this study by watering pots to field capacity or limiting soil

271 moisture to simulate drought stress in A. californica seedlings, and found that 
272 inoculum from high $\mathrm{N}$ deposition soil was especially detrimental under drought

273 stress (Valliere and Allen 2016).

274 In a greenhouse study by Sigüenza et al. (2006a), as in the field (Sigüenza et

275 al. 2006b), B. rubens was colonized by fine AMF hyphae, likely Glomus tenue, while $A$.

276 californica was colonized by coarse hyphae. The negative response of $A$. californica

277 seedlings to AMF colonization may be related to the high P (30 $\mu \mathrm{g} \mathrm{g}^{-1}$; Padgett et al.

278 1999) of these soils, as high P may cause growth reductions in mycorrhizal plants,

279 especially at the seedling stage (e.g., Johnson et al. 1997; Allen et al. 2003).

280 Alternatively, Glomus tenue may have promoted a positive growth response in $B$.

281 rubens in these high P soils under low $\mathrm{N}$ relative to sterile controls. Under elevated

$282 \mathrm{~N}$, there was no significant difference in biomass response to inoculation in the

283 greenhouse experiment, even though there was a reduction in percent mycorrhizal

284 colonization in high N deposition soil (Sigüenza et al. 2006a). Nonmycorrhizal,

285 potentially pathogenic fungi were also assessed microscopically in this study, and

286 their colonization was greater for both species only in one treatment, high $\mathrm{N}$

287 deposition inoculum under high N fertilizer (Sigüenza et al. 2006a), so incidence of

288 pathogens does not explain the growth responses in this study. These findings

289 suggest that $G$. tenue is an effective mutualist even at low levels of root colonization

290 and under high soil N availability, (Hilbig and Allen 2015). Glomus tenue (syn.

291 Rhizophagus tenuis) is commonly found in soils of harsh and disturbed

292 environments (Olsson et al. 2004), and is considered to be more frequent in pioneer

293 plants (Blaschke 1991). A positive feedback from G. tenue was also found to

294 contribute to the overall success of the exotic annual Bromus diandrus by 
295 compensating for negative impacts of putative pathogens in an abandoned

296 agricultural field (Hilbig and Allen 2015).

\section{Conclusions}

299 By synthesizing a series of studies on AMF and plant response with recently 300 available data on $\mathrm{N}$ deposition (Fenn et al. 2010), we have shown that AMF may be

301 an important indicator of CL for $\mathrm{N}$ deposition, and may also have an central role in

302 the vegetation-type conversion of coastal sage scrub to exotic annual grassland.

303 Threshold losses in AMF morphospecies richness, native plant species richness, and

304 vegetation-type conversion from native shrubland to exotic annual grassland all

305 occurred at 10-11 $\mathrm{kg} \mathrm{N} \mathrm{ha}^{-1} \mathrm{yr}^{-1}$. These losses in AMF diversity co-occurred with a

306 decrease in AMF root colonization in A. californica but not B. rubens in field-

307 collected samples (Sigüenza and Allen 2006a). Furthermore, AMF of A. californica

308 are sensitive to elevated N, producing small seedlings that are likely unable to

309 compete with fast-growing $B$. rubens with fine AMF that are insensitive to elevated N

310 (Sigüenza and Allen 2006b). By combining these studies, we suggest that processes

311 occurring on very small scales of individual plant-mycorrhizal interactions can have

312 ramifications on the landscape scale for vegetation-type conversion under the

313 impact of $\mathrm{N}$ deposition.

$314 \quad$ Further evidence for AMF-induced vegetation changes may come by studying

315 additional invasive and native species of CSS, and by expanding these studies to

316 other ecosystem types. For instance, a closely related invasive grass, $B$. tectorum, is

317 causing vegetation type conversion throughout Artemisia tridentata shrublands of 
318 the western U.S. even in the absence of $\mathrm{N}$ deposition, but most of the invasion

319 appears to be in soils that are naturally high in N and P (Belnap et al. 2016). Losses

320 of richness in European grasslands and shrublands is not related to invasive species,

321 but rather to increases in native grass species under $\mathrm{N}$ deposition (Bobbink et al.

322 2010; Stephens et al. 2010). The role of AMF under changing nutrients has been

323 little explored in these situations of species loss, and deserves further study.

\section{Acknowledgements}

326 This review was inspired by E.B. Allen's participation in the "Diversity and Nitrogen

327 Deposition" working group supported by the John Wesley Powell Center for

328 Analysis and Synthesis, funded by the U.S. Geological Survey. We thank Robert

329 Johnson, Center for Conservation Biology, UCR, for preparing Fig. 1.

330 


\section{$331 \quad$ References}

332 Allen, E.B., Padgett, P.E., Bytnerowicz, A., and Minnich, R.A. 1998. Nitrogen

333 deposition effects on coastal sage vegetation of southern California. In

334 Proceedings of the International Symposium on Air Pollution and Climate

335 Change Effects on Forest Ecosystems. Technical Coordinator, A. Bytnerowicz.

336 USDA Forest Service, Pacific Southwest Research Station. pp. 131-140.

337 http://www.fs.fed.us/psw/publications/documents/psw_gtr166/ (Accessed

$338 \quad$ December 9, 2015)

339 Allen, E.B., Rao, L.E., Tonnesen, G., Johnson, R.F., Fenn, M.E., and Bytnerowicz, A.

340 2014. Using fire risk and species loss to set critical loads for $\mathrm{N}$ deposition in

341 southern California shrublands. Chapter 34. In Nitrogen Deposition, Critical

342 Loads and Biodiversity (Proceedings of the International Nitrogen Initiative

343 workshop, Linking Experts of the Convention on Long-range Transboundary

344 Air Pollution and the Convention on Biological Diversity). Edited by M.A. Sutton,

345 K.E. Mason, L.J. Sheppard, H. Sverdrup, R. Haeuber, and W.K. Hicks. Springer

$346 \quad$ Science. pp. 319-327.

347 Allen, M.F., Allen, E.B., Lansing, J.L., Pregitzer, K.S., Hendrick, R.L., Ruess, R.W., and

348 Collins, S.L. 2010. Responses to chronic N fertilization of ectomycorrhizal

349 pinon but not arbuscular mycorrhizal juniper in a pinon-juniper woodland.

$350 \quad$ Journal of Arid Environments 74(10): 1170-1176.

351 Allen, M.F., Swenson, W., Querejeta, J.I., Egerton-Warburton, L.M., and Treseder, K.K.

352 2003. Ecology of mycorrhizae: A conceptual framework for complex

353 interactions among plants and fungi. Annual Review of Phytopathology 41: 

271-303. $<$ Go to ISI >://000186493900013

355 Bytnerowicz, A., Fenn, M.E., Allen, E.B., and Cisneros, R. 2016. Ecologically relevant 356 atmospheric chemistry. Chapter 7. In Ecosystems of California Edited by E.

357 Zavaleta, and H.A. Mooney. University of California Press, Berkeley. pp. 107$358 \quad 128$.

359 Barto, E.K., Antunes, P.M., Stinson, K., Koch, A.M., Klironomos, J.N., and Cipollini, D.

360 2011. Differences in arbuscular mycorrhizal fungal communities associated 361 with sugar maple seedlings in and outside of invaded garlic mustard forest

363 Belnap, J., Stark, J.M., Rau, B.M., Allen, E.B., and Phillips, S. 2016. Soil moisture and 364 biogeochemical factors influence the distribution of annual Bromus species. In Exotic Brome-Grasses in Arid and Semi-Arid Ecosystems of the Western US: Causes, Consequences, and Management Implications. Environmental Management Series. Edited by J.C. Chambers, M.J. Germino, and C.S. Brown.

369 Blaschke, H. 1991. Multiple mycorrhizal associations of individual calcicole host plants in the alpine grass-heath zone. Mycorrhiza 1: 31-34.

371 Bobbink, R., Hicks, K., Galloway, J., Spranger, T., Alkemade, R., Ashmore, M.,

372 Bustamante, M., Cinderby, S., Davidson, E., Dentener, F., Emmett, B., Erisman, 373 J.W., Fenn, M., Gilliam, F., Nordin, A., Pardo, L., and De Vries, W. 2010. Global

374 assessment of nitrogen deposition effects on terrestrial plant diversity: a 375 synthesis. Ecological Applications 20(1): 30-59. 
376 Burrows, R.L., and Pfleger, F.L. 2002. Arbuscular mycorrhizal fungi respond to

377

378

379

380

381

382

383

384

385

386

387

388

389

390

391

392

393

394

395

396 increasing plant diversity. Canadian Journal of Botany-Revue Canadienne De Botanique 80(2): 120-130.

Busby, R.R., Stromberger, M.E, Rodriguez G., Gebhart, D.L., and Paschke, M.W. 2012. Arbuscular mycorrhizal fungal community differs between coexisting native shrub and introduced annual grass. Mycorrhiza 23: 129-141.

Cleland, E.E., Funk, J., and Allen, E.B. 2016. Coastal Sage Scrub. Chapter 22. In Ecosystems of California. Edited by E. Zavaleta, and H.A. Mooney. University of California Press, Berkeley. pp. 429- 448.

Cox, R.D., and Allen, E.B. 2008. Stability of exotic annual grasses following restoration efforts in southern California coastal sage scrub. Journal of Applied Ecology 45(2): 495-504.

Cox, R.D., Preston, K.L., Johnson, R.F., Minnich, R.A., and Allen, E.B. 2014. Influence of landscape-scale variables on vegetation conversion in southern California, USA. Global Ecology and Conservation 2(Open Access): 190-203. Available from doi:10.1016/j.gecco.2014.09.008 (Accessed 9 December 2015).

Dirnbock, T., Grandin, U., Bernhardt-Romermann, M., Beudert, B., Canullo, R., Forsius, M., Grabner, M.T., Holmberg, M., Kleemola, S., Lundin, L., Mirtl, M., Neumann, M., Pompei, E., Salemaa, M., Starlinger, F., Staszewski, T., and Uzieblo, A.K. 2014. Forest floor vegetation response to nitrogen deposition in Europe. Global Change Biology 20(2): 429-440. 
397 Egerton-Warburton, L.M., and Allen, E.B. 2000. Shifts in arbuscular mycorrhizal 398 communities along an anthropogenic nitrogen deposition gradient. Ecological

400 Egerton-Warburton, L.M., Graham, R.C., Allen, E.B., and Allen, M.F. 2001. Applications 10(2): 484-496. Reconstruction of the historical changes in mycorrhizal fungal communities under anthropogenic nitrogen deposition. Proceedings of the Royal Society of London Series B-Biological Sciences 268(1484): 2479-2484.

Egerton-Warburton, L.M., Johnson, N.C., and Allen, E.B. 2007. Mycorrhizal community dynamics following nitrogen fertilization: A cross-site test in five grasslands. Ecological Monographs 77(4): 527-544.

Eliason, S.A., and Allen, E.B. 1997. Exotic grass competition in suppressing native shrubland re-establishment. Restoration Ecology 5(3): 245-255.

Fenn, M.E., Allen, E.B., Weiss, S.B., Jovan, S., Geiser, L.H., Tonnesen, G.S., Johnson, R.F., Rao, L.E., Gimeno, B.S., Yuan, F., Meixner, T., and Bytnerowicz, A. 2010. Nitrogen critical loads and management alternatives for $\mathrm{N}$-impacted ecosystems in California. Journal of Environmental Management 91(12): 2404-2423.

Fenn, M.E., Baron, J.S., Allen, E.B., Rueth, H.M., Nydick, K.R., Geiser, L., Bowman, W.D., Sickman, J.O., Meixner, T., Johnson, D.W., and Neitlich, P. 2003. Ecological effects of nitrogen deposition in the western United States. Bioscience 53(4): 404-420.

Hilbig, B.E., and Allen, E.B. 2015. Plant-soil feedbacks and competitive interactions 18 between invasive Bromus diandrus and native forb species. Plant and Soil 392(1-2): 191-203. 
420 Huenneke, L.F., Hamburg, S.P., Koide, R., Mooney, H.A., and Vitousek, P.M. 1990.

421 Effects of soil resources on plant invasion and community structure in

$422 \quad$ Californian serpentine grassland. Ecology 71(2): 478-491.

423 Klironomos, J.N. 2003. Variation in plant response to native and exotic arbuscular

$424 \quad$ mycorrhizal fungi. Ecology 84(9): 2292-2301.

425 Johnson, N.C. 1993. Can fertilization of soil select less mutualistic mycorrhizae?

$426 \quad$ Ecological Applications 3(4): 749-757.

427 Johnson, N.C., Graham, J.H., and Smith, F.A. 1997. Functioning of mycorrhizal

428 associations along the mutualism-parasitism continuum. New Phytologist

$429 \quad$ 135(4): 575-586.

430 Johnson, N.C., Rowland, D.L., Corkidi, L., Egerton-Warburton, L.M., and Allen, E.B.

431 2003. Nitrogen enrichment alters mycorrhizal allocation at five mesic to

432 semiarid grasslands. Ecology 84(7): 1895-1908.

433 Marler, M.J., Zabinski, C.A., and Callaway, R.M. 1999. Mycorrhizae indirectly enhance

434 competitive effects of an invasive forb on a native bunchgrass. Ecology $\mathbf{8 0}(4)$ :

$435 \quad 1180-1186$.

436 Mummey, D.L., and Rillig, M.C. 2006. The invasive plant species Centaurea maculosa 437 alters arbuscular mycorrhizal fungal communities in the field. Plant and Soil

438 288(1-2): 81-90.

439 NADP 2013. National Atmospheric Deposition Program Total N Deposition Maps.

$440 \quad$ http://nadp.isws.illinois.edu/committees/tdep/tdepmaps/preview.aspx\#n td

$441 \quad$ (Accessed December 9, 2015). 
442 Olsson, P.A., Eriksen, B.E., and Dahlberg, A. 2004. Colonization by arbuscular

443 mycorrhizal and fine endophytic fungi in herbaceous vegetation in the 444 Canadian High Arctic. Canadian Journal of Botany-Revue Canadienne De $445 \quad$ Botanique 82(11): 1547-1556.

446 Padgett, P.E., Allen, E.B., Bytnerowicz, A., and Minnich, R.A. 1999. Changes in soil 447 inorganic nitrogen as related to atmospheric nitrogenous pollutants in $448 \quad$ southern California. Atmospheric Environment 33(5): 769-781.

449 Pardo, L.H., Fenn, M.E., Goodale, C.L., Geiser, L.H., Driscoll, C.T., Allen, E.B., Baron, J.S.,

450 Bobbink, R., Bowman, W.D., Clark, C.M., Emmett, B., Gilliam, F.S., Greaver, T.L., 451 Hall, S.J., Lilleskov, E.A., Liu, L.L., Lynch, J.A., Nadelhoffer, K.J., Perakis, S.S., 452 Robin-Abbott, M.J., Stoddard, J.L., Weathers, K.C., and Dennis, R.L. 2011. Effects 453 of nitrogen deposition and empirical nitrogen critical loads for ecoregions of 454 the United States. Ecological Applications 21(8): 3049-3082.

455 Pringle, A., Bever, J.D., Gardes, M., Parrent, J.L., Rillig, M.C., and Klironomos, J.N. 2009.

$456 \quad$ Mycorrhizal Symbioses and Plant Invasions. Annual Review of Ecology

$457 \quad$ Evolution and Systematics 40: 699-715.

458 Querejeta, J.I., Egerton-Warburton, L.M., Prieto, I., Vargas, R., and Allen, M.F. 2012.

459 Changes in soil hyphal abundance and viability can alter the patterns of 460 hydraulic redistribution by plant roots. Plant and Soil 355(1-2): 63-73.

461 Rao, L.E., Allen, E.B., and Meixner, T. 2010. Risk-based determination of critical 462 nitrogen deposition loads for fire spread in southern California deserts. $463 \quad$ Ecological Applications 20(5): 1320-1335. 
464 Rao, L.E., and Allen, E.B. 2010. Combined effects of precipitation and nitrogen

465 deposition on native and invasive winter annual production in California 466 deserts. Oecologia 162(4): 1035-1046.

467 Sigüenza, C., Corkidi, L., and Allen, E.B. 2006a. Feedbacks of soil inoculum of

468 mycorrhizal fungi altered by $\mathrm{N}$ deposition on the growth of a native shrub and

469 an invasive annual grass. Plant and Soil 286(1-2): 153-165.

470 Sigüenza, C., Crowley, D.E., and Allen, E.B. 2006b. Soil microorganisms of a native

471 shrub and exotic grasses along a nitrogen deposition gradient in southern

472 California. Applied Soil Ecology 32(1): 13-26.

473 Steers, R.J., Funk, J.L., and Allen, E.B. 2011. Can resource-use traits predict native vs.

474 exotic plant success in carbon amended soils? Ecological Applications 21(4):

$475 \quad 1211-1224$.

476 Stevens, C.J., Dupre, C., Dorland, E., Gaudnik, C., Gowing, D.J.G., Bleeker, A., Diekmann, 477 M., Alard, D., Bobbink, R., Fowler, D., Corcket, E., Mountford, J.O., Vandvik, V., 478 Aarrestad, P.A., Muller, S., and Dise, N.B. 2010. Nitrogen deposition threatens 479 species richness of grasslands across Europe. Environmental Pollution 158(9): $480 \quad 2940-2945$.

481 Suding, K.N., Collins, S.L., Gough, L., Clark, C., Cleland, E.E., Gross, K.L., Milchunas, D.G., 482 and Pennings, S. 2005. Functional- and abundance-based mechanisms explain 483 diversity loss due to $\mathrm{N}$ fertilization. Proceedings of the National Academy of 484 Sciences of the United States of America 102(12): 4387-4392. 
485 Valliere, J.M. and Allen. E.B. 2016. Interactive effects of nitrogen deposition and 486 drought-stress on plant-soil feedbacks of Artemisia californica seedlings. Plant $487 \quad$ and Soil, in press.

488 van Diepen, L.T.A., Lilleskov, E.A., and Pregitzer, K.S. 2011. Simulated nitrogen

489 deposition affects community structure of arbuscular mycorrhizal fungi in 490 northern hardwood forests. Mol. Ecol. 20(4): 799-811.

491 Weiss, S.B. 1999. Cars, cows, and checkerspot butterflies: Nitrogen deposition and 492 management of nutrient-poor grasslands for a threatened species.

493 Conservation Biology 13(6): 1476-1486.

494 Yoshida, L.C., and Allen, E.B. 2001. Response to ammonium and nitrate by a 495 mycorrhizal annual invasive grass and native shrub in southern California. 496 American Journal of Botany 88(8): 1430-1436.

497 Yoshida, L.C., and Allen, E.B. 2004. N-15 uptake by mycorrhizal native and invasive 498 plants from a N-eutrophied shrubland: a greenhouse experiment. Biology and $499 \quad$ Fertility of Soils 39(4): 243-248.

500 
1 Table 1. Percent cover and richness (number of species per 3 ha) of plant groups

2 along an $\mathrm{N}$ deposition gradient in western Riverside County. Sites are arranged from

3 north to south along an urban to rural gradient. Forb species richness in bold shows

4 a rapid drop in richness, suggesting a critical load of $10 \mathrm{~kg} \mathrm{~N} \mathrm{ha}^{-1} \mathrm{y}^{-1}$ based on the

$5 \quad$ CMAQ model of N deposition (Fenn et al. 2010).

\begin{tabular}{|c|c|c|c|c|c|c|}
\hline Site & $\begin{array}{l}\text { Exotic } \\
\text { grass \% }\end{array}$ & $\begin{array}{l}\text { Native } \\
\text { forb }\end{array}$ & $\begin{array}{c}\text { Shrub } \\
\text { \% }\end{array}$ & $\begin{array}{c}\text { \# Native } \\
\text { forb }\end{array}$ & $\begin{array}{l}\text { Soil N } \\
\mu \mathrm{g} \mathrm{g}^{-1}\end{array}$ & 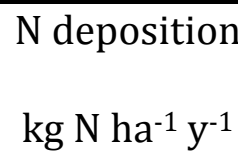 \\
\hline & cover & $\%$ cover & cover & species & & \\
\hline Jurupa Hills & 63.5 & 4.0 & 2.2 & 16 & 37.7 & 19.6 \\
\hline Box Springs & 69.2 & 18.5 & 2.4 & 31 & 32.6 & 14.7 \\
\hline \multicolumn{7}{|l|}{ Botanic } \\
\hline Garden & 36.0 & 25.4 & 0.2 & 20 & 28.9 & 13.4 \\
\hline Lake Perris & 0.5 & 26.1 & 2.8 & 30 & 20.3 & 11.1 \\
\hline Mott Reserve & 6.7 & 14.3 & 11.2 & 37 & 30.6 & 11.1 \\
\hline \multicolumn{7}{|l|}{ Lopez } \\
\hline Canyon & 11.1 & 19.6 & 19.3 & 67 & 9.6 & 9.0 \\
\hline \multicolumn{7}{|l|}{ Tucalota } \\
\hline Hills & 1.5 & 35.7 & 35.0 & 50 & 10.5 & 8.7 \\
\hline
\end{tabular}

6 
8 Table 2. Spore counts and percent root colonization of AMF along a N deposition

9 gradient in western Riverside County. Sites are arranged from north to south along

10 an urban to rural gradient (data from Egerton-Warburton and Allen 2000). Values in

11 bold show a drop in spore density and root infection and are interpreted to

12 represent a critical load.

\begin{tabular}{lcccc}
\hline \multicolumn{1}{c}{ Site } & Spores/ & \% root & Soil N & N deposition \\
& g soil & colonization & $\mu g^{-1}$ & $\mathrm{~kg} \mathrm{~N} \mathrm{ha}^{-1} \mathrm{y}^{-1}$ \\
\hline Jurupa Hills & 23 & 19 & 86.2 & 19.6 \\
Waterman Rd. & 54 & 18 & 15.6 & 16.9 \\
Box Springs Mt. & 66 & 17 & 26.4 & 14.7 \\
Mockingbird Cyn & 74 & 24 & 56.8 & 12.5 \\
Lake Mathews & 70 & 23 & 39.5 & $\mathbf{1 1 . 1}$ \\
Motte Reserve & 80 & 27 & 26.1 & $\mathbf{1 1 . 1}$ \\
Hemet & $\mathbf{7 8}$ & $\mathbf{2 2}$ & 12.8 & $\mathbf{9 . 6}$ \\
Lake Skinner & $\mathbf{1 0 3}$ & $\mathbf{3 9}$ & 7.5 & $\mathbf{8 . 7}$ \\
Santa Margarita & 105 & 45 & 9.7 & 8.7 \\
\hline
\end{tabular}

13 
14 Table 3. Diversity of AMF spores decreased with increasing extractable soil N along the N deposition gradient of Western

15 Riverside County. Many large-spored species failed to reproduce in high-N soil (Egerton-Warburon and Allen 2000). Modeled

16 N deposition values from Fenn et al. (2010).

\begin{tabular}{|l|c|c|c|c|c|c|c|c|}
\hline & Santa & Lake & & Motte & Lake & Mocking- & Box Springs & Jurupa \\
Site & Margarita & Skinner & Hemet & Reserve & Mathews & bird Cyn & Mt. \\
\hline Soil N $\left(\mu \mathrm{g} \mathrm{g}^{-1}\right)$ & 9.7 & 7.5 & 12.8 & 26.1 & 35.0 & 39.5 & 26.4 & 86.2 \\
N deposition $\left(\mathrm{kg} \mathrm{N} \mathrm{ha-1}^{-1}\right)$ & 8.7 & 8.7 & 9.6 & 11.1 & 12.5 & 12.5 & 14.7 & 19.6 \\
Diversity (H') & 0.766 & 0.564 & 0.269 & 0.422 & 0.579 & 0.315 & 0.163 & 0.243 \\
No. AMF species & 19 & 19 & 11 & 18 & 15 & 14 & 14 & 12 \\
No. Large-spored taxa & 7 & 4 & 2 & 4 & 4 & 2 & 1 \\
\% Large-spored taxa & 36.8 & 21.1 & 18.2 & 22.2 & 26.7 & 14.3 & 7.1 \\
\hline
\end{tabular}




\section{Figure Captions}

Fig. 1 Nitrogen deposition in western Riverside County, southern California, showing a gradient $60 \mathrm{~km}$ long that ranges from 8.7 to $19.6 \mathrm{~kg} \mathrm{~N} \mathrm{ha}^{-1} \mathrm{yr}^{-1}$ and lies within coastal sage scrub vegetation. Map created by Robert Johnson, Center for Conservation Biology, UC Riverside.

Fig. 2. A.) Percent cover of native shrubs following a 1993 fire in coastal sage scrub in plots that were fertilized with $\mathrm{N}$ and controls. B.) Biomass of exotic grass Bromus rubens in control and $\mathrm{N}$ fertilized treatment. $\mathrm{P}$ indicates significance for repeated measures analysis, ${ }^{*}=\mathrm{P}<0.05$ for individual dates (E. Allen, unpublished data).

Fig. 3. Greenhouse growth responses of the invasive grass Bromus rubens and the native shrub Artemisia californica to soil inoculum from sites with low and high N deposition compared to sterile soil (NM = nonmycorrhizal) under two levels of levels of soil $\mathrm{N}$ fertilizer. Different letters indicate significantly different at $\mathrm{P}<0.05$. Redrawn using data from Sigüenza and Allen (2006a). 


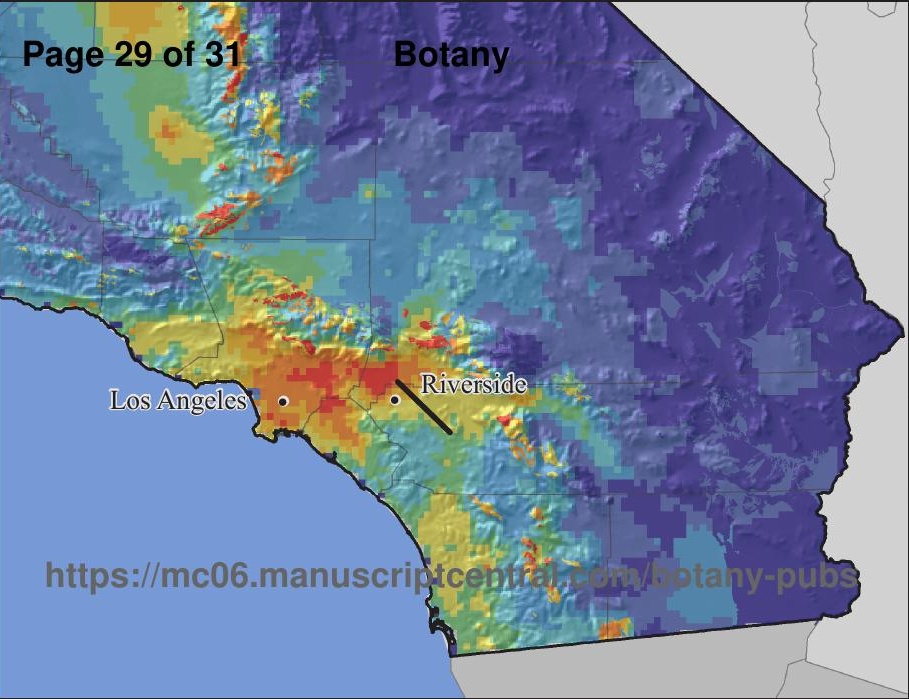



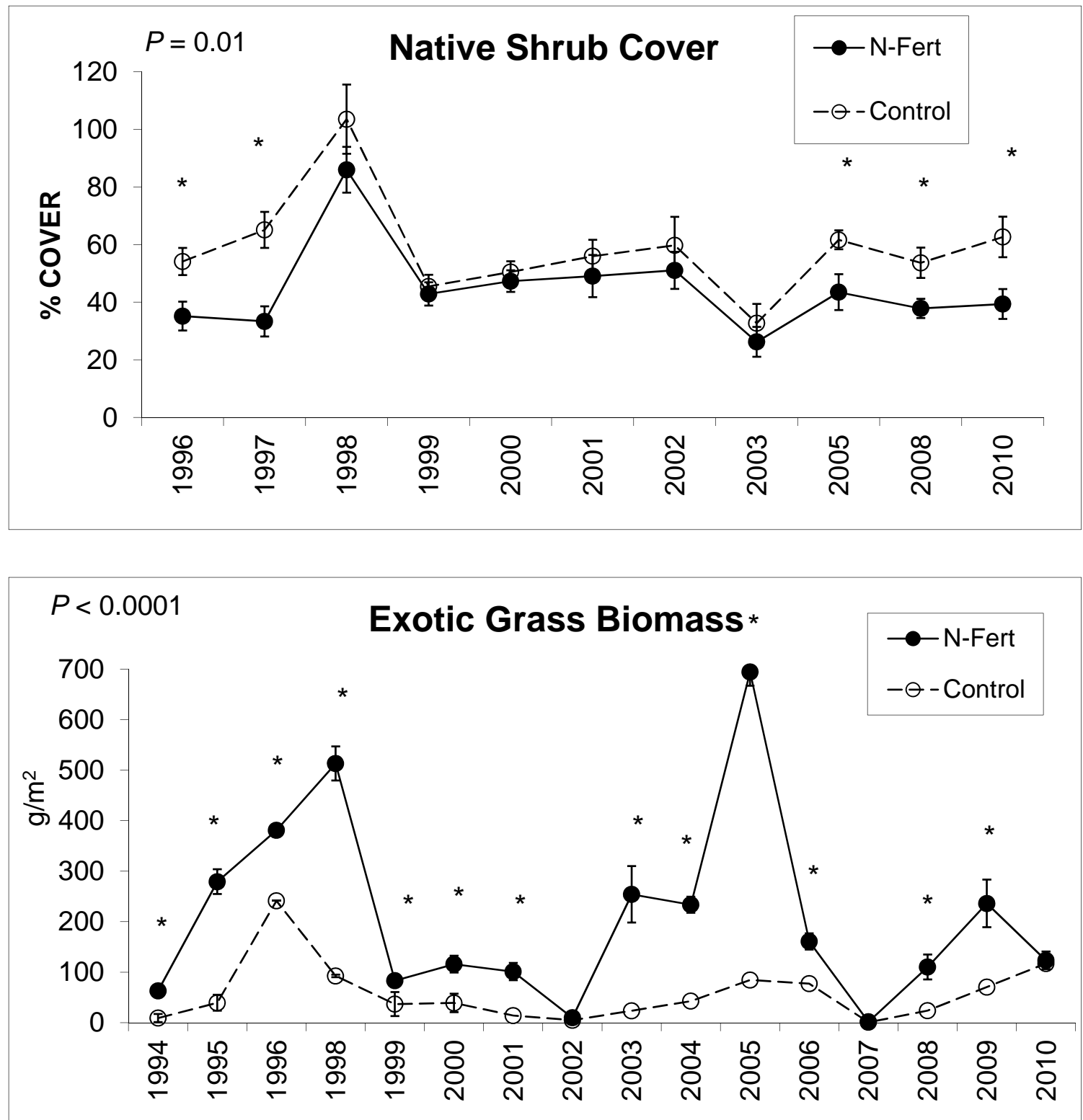

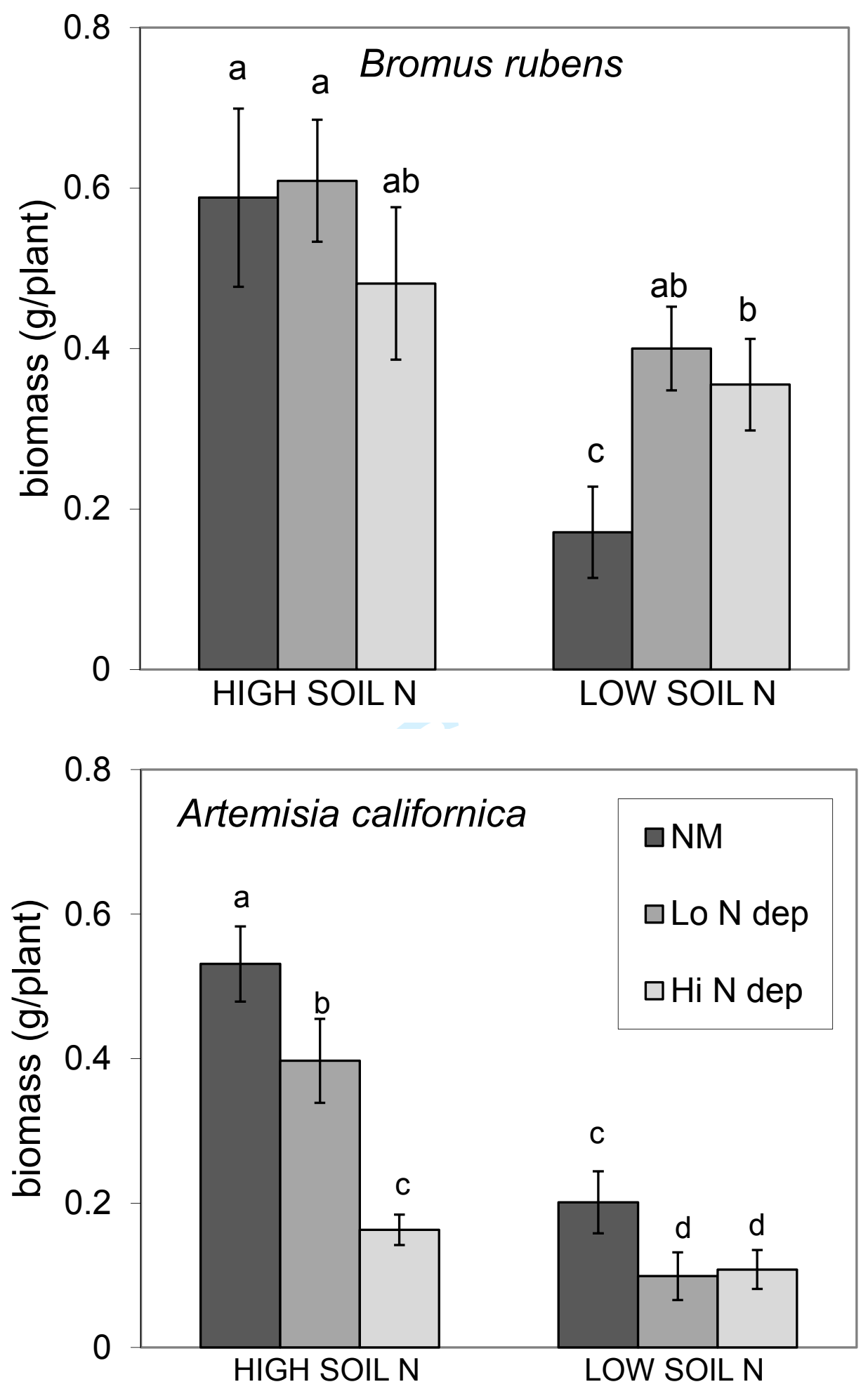